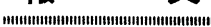

\title{
柑橘園におけるミカン八ダニのへキシチアゾクス による圑場淘汰試験*
}

\author{
山本 敦 司, 米田 渥**, 波多野連平, 浅田三津男 \\ 日本曹達株式会社小田原研究所 \\ **日本曹達株式会社磐梯農場
}

(平成 7 年 4 月 24 日受理)

\author{
Field Selection Experiments with Hexythiazox in the Citrus \\ Red Mite, Panonychus citri (McGregor)* \\ Atsushi Yamamoto, Hiromi Yoneda, ${ }^{* *}$ Renpei Hatano \\ and Mitsuo Asada \\ Odawara Research Center, Nippon Soda Co., Ltd., Takada, Odawara 250-02, Japan \\ **Bandai Agricultural Research Station, Nippon Soda Co., Ltd., \\ Yama-gun, Fukushima 969-33, Japan
}

\begin{abstract}
As a part of hexythiazox resistance risk assessments in the citrus red mite, Panonychus citvi (MCGREGOR), a field selection experiment was performed in a citrus orchard consisting of 24 trees at Haibara Agricultural Research Station (Nippon Soda Co., Ltd.) in Shizuoka Prefecture, Japan. A high level of hexythiazox resistance developed slowly by 18 successive selections $(25 \mathrm{ppm})$ during 6 years, and $\mathrm{LC}_{50}$ reached over $8000 \mathrm{ppm}$. During the first 4 years, $2-3$ times of application a year were sufficient for successful control of the mites, whereas as many as 4 times of treatment a year were needed for the last 2 years of the experiment. Differences were observed not only in population density but also susceptibility to hexythiazox among the mite populations on different trees in the citrus orchard used for the test. In this study, hexythiazox resistance seemed to develop patchily in a specific population of citrus red mite on a tree within the orchard.
\end{abstract}

(Received March 8, 1995; Accepted April 24, 1995)

\section{緒 \\ ヘキシチアゾクス (hexythiazox: trans-5-(4-chlo- rophenyl)- $N$-cyclohexyl-4-methyl-2-oxo-3-thiazo- lidine-carboxamide) は, 農業上重要な各種ハダニ類 に活性を示し, チリカブリダニ (Phytoseiulus persimi- lis Athias-HenRIoT) やハネカクシの一種 (Oligota sp.) のような天敵やミッバチ (Apis mellifera LINNE)}

*植食性ハダニ類のヘキシチアゾクス抵抗性に関する 研究 (第 1 報).

Studies on Hexythiazox Resistance in Phytophagous Mites (Part 1).
のような有益昆虫に影響のない選択的殺ダ二成である。 ヘキシチアゾクスはハダニ類の卵, 幼虫および若虫に対 して殺ダニ作用を示すだけでなく，処理雌成虫の産下卵 に対し孵化抑制作用も示す．また，固場における残効性 女長い1).

ミカンハダニ (Panonychus citvi McGREGOR) は柑 檑に寄生する重要害虫であり, 繁殖力が旺盛で, ライフ サイクルが短く年間世代数が多いことから ${ }^{2,3)}$ 大きな被 害をもたらす. ミカンハダニを防除するため，これまで にも多くの殺ダニ剂が用いられてきたが，八ダ二類の生 物的および生態的特性から薬剂抵抗性発達は比較的速 く ${ }^{4,5)}$, 抵抗性回避ができず大きな問題となっていた。 
ヘキシチアゾクスは 1980 年に発明され，1985 年に 日本で登録になった．本化合物は，総合的害虫管理の一 端を担う殺ダニ剤として各種ハダニ類の防除に使用さ れ，作用性が異なるため既存の薬剤とは交差抵抗性を示 さないものとして位置づけられている1). しかしながら，

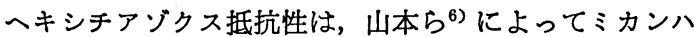
ダニで 1987 年に初めて確認されて以来, リンゴハダニ

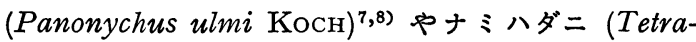
nychus urticae $\mathrm{KocH})^{9)}$ でも報告された.

筆者らは，抵抗性によるリスクを予測し対応策を考慮

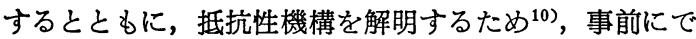
きるたけ抵抗性に関する情報を得ることが重要と考兄， ヘキシチアゾクスが登録される以前から，へキシチアゾ クス抵抗性研究に着手した，本研究ではその一環として 行なった，野外の柑橘園におけるへキシチアゾクス連用 による淘汰試験の結果について報告する。

\section{材 料 と方 法}

\section{1. ミカンハダニ}

ヘキシチアゾクスによる淘汰試験は，静岡県棒原郡榛 原町の日本曹達株式会社榛原農業研究所内の柑柏園で行 なった．この柑橘園は $130 \mathrm{~m}^{2}$ の面積をもち，北東面と 南東面には別の柑滒園が隣接しているほかは雑木林に团 まれていた。ここには，10 年生の青島温州 24 本が植樹 されていた(Fig. 1)．試験開始前に，農林水産省果樹試 験場興津支場柑橘園 (静岡県), 静岡県柑橘試験場柑橋園 (静岡県), 静岡県榛原郡, 静岡県三方原, 奈良県, 佐賀 県, 熊本県の各一般農家柑埛園, 日本曹達株式会社生物 科学研究所柑橘園 (神奈川県) からミカン八ダニ (卵か ら成虫) の寄生葉を分譲していただいた。ミカンハダニ が増加途上にある 1980 年 5 月 17 日から 6 月 12 日に
わたって，分譲されたミカンハダニ寄生葉を試験に用い た相㛢園に放飼した。ミカンハダニが十分増加した（約 500 頭/100 葉) 6 月 20 日に, 柑瀮園の 24 樹から均等 にミカン八ダニ（卵から成虫）の寄生葉を採集し，無淘 汰系統としてガラス温室内で鉢植えの相極幼木（青島温 州）を用いて飼育を続けた。

\section{2. ヘキシチアゾクスによる淘汰およびその他の薬剛} 散布

ヘキシチアゾクス $(10 \% \mathrm{WP})$ による淘汰として, $25 \mathrm{ppm}$ の濃度で 20〜90l の薬液を，動力噴等器を用 いて柑绣園内の 24 樹に均等に散布した (Table 1). へ キシチアゾクスによる淘汰は，ミカン八ダニ雌成虫の寄 生密度が，要防除密度の 1 葉当り 1 匹を超えた場合に 行なった。また，一般の病害虫防除は極力減らしたが， 必要に応じて適宜殺菌剤 (thiophanate-methyl 等) と殺虫剂（carbaryl 等）を慣行の濃度で散布した。

\section{3. 感受性検定}

淘汰に伴うへキシチアゾクス感受性の変化をモニター するため，へキシチアゾクスによる淘汰後八ダニ密度が 十分增加した時点に感受性検定を行なった．相橋園の 24 樹よりあらかじめ選んだ 10 本の調查樹 (Fig. 1) か ら均等にミカン八ダニの寄生葉を採集し，固場淘汰系統 とした.また薬剤感受性の季節的変動を考慮するため ${ }^{11)}$, 無淘汰系統のミカン八ダニの感受性も同時に検定した。 感受性検定は，殺卵武験で行なった。ミミカ葉片にミカ ンハダニの雌成虫を $10 \sim 15$ 頭接種し，48 時間産卵さ せた後，成虫を除去した。ミミン葉片は，乾燥を防ぐた めに濡らした脱脂綿とともに，直径 $9 \mathrm{~cm}$ のガラス製の シャーレに収めた．産下卵に対して，所定濃度に希釈し たへキシチアゾクス $10 \%$ 水和剤を，回転散布塔（みず ほ理科(株)，名古屋）を用いて散布処理を行なった（2 (a)

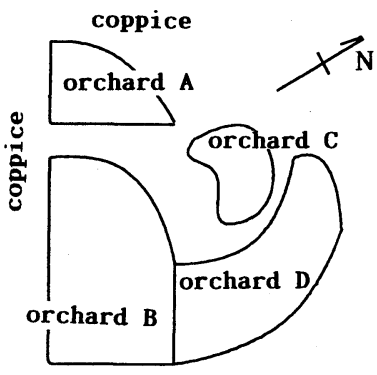

(b)

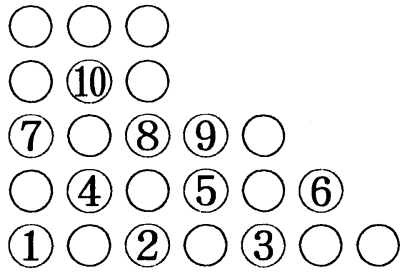

Fig. 1 Location of a citrus orchard (a) and trees in the citrus orchard (b) used for the field selection experiment with hexythiazox.

(a) The orchard A, $130 \mathrm{~m}^{2}$ in size, was used for the experiment. (b) Circles and ones with number represent citrus trees and trees investigated, respectively. 


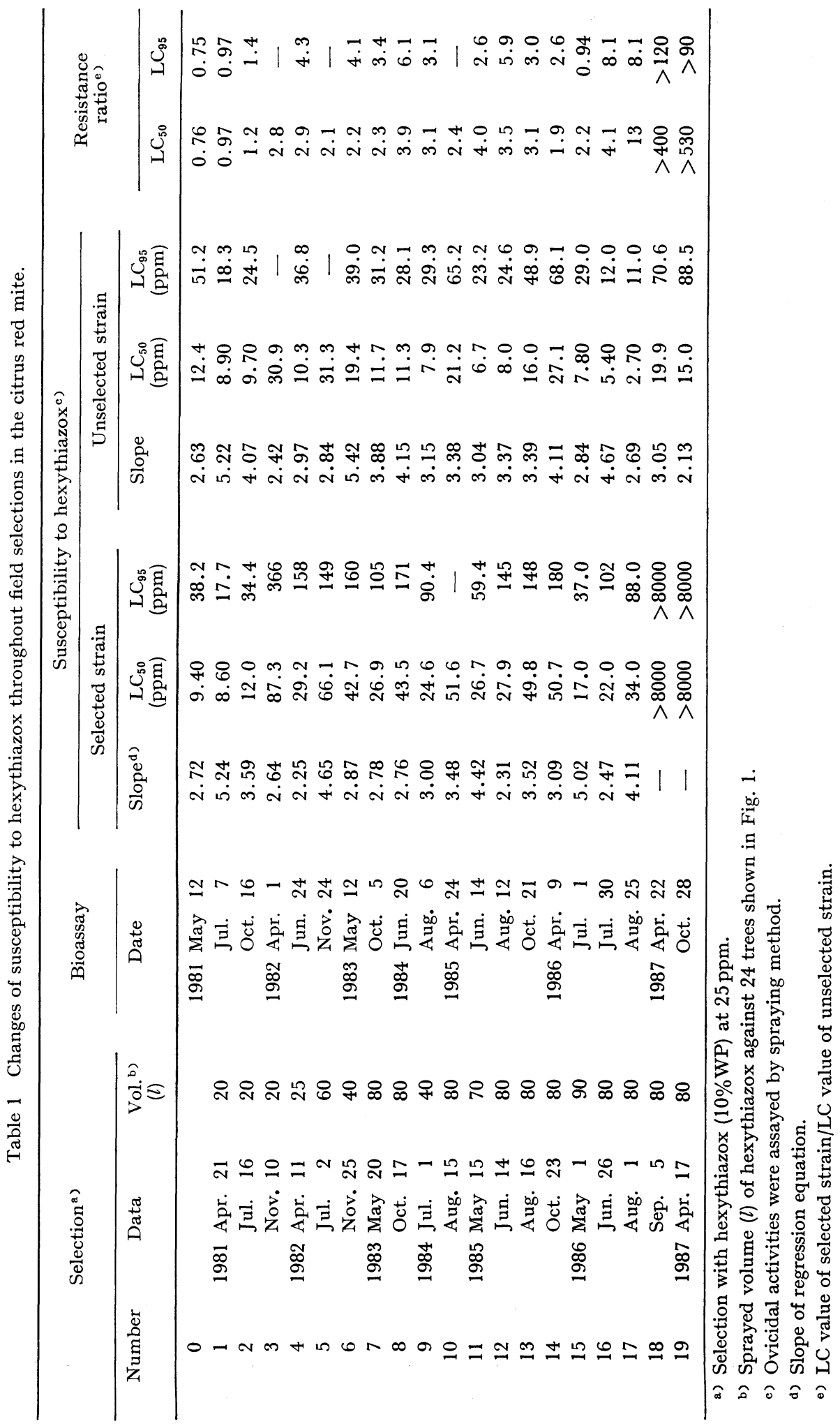


$\mathrm{mg} / \mathrm{cm}^{2}, 3$ 反復 $)^{12)}$. 処理 7 日後に末卯化卵を調查し, アボットの補正を施した後 ${ }^{13)}$ プロビット分析を行なっ た ${ }^{14)}$.

ヘキシチアゾクス抵抗性の発達が確認された直後に， ミカン八ダニのへキシチアゾクスに対する感受性の寄生 樹間における違いを調査した。樹 No. 1，No. 5, No. 6, No. 7 および No. 9 の各樹に寄生する戋場淘汰系統 および無淘汰系統のミカンハダ二雌成虫の産下即 $(0 \sim$ 3 日間）に対して，上記の方法で散布処理した．処理 14 日後に生存成虫数を調査し, 次の式で発育阻害力 （産下卵が成虫まで発育できなかった割合）を計算した。 発育阻害力 $=[($ 供試卵数一生存成虫数 $) /$ 供試卵数 $] \times 100$
感受性検定はすべて， $25 \pm 1^{\circ} \mathrm{C}$ ，相対湿度 $65 \pm 5 \%$ お よび 16 時間日長に設定した恒温室で行なった。

\section{4. 個体群密度調查}

ミカンハダニの発生消長を, 1981 年から 1987 年に わたり 3 月から 12 月の間に約 15 日間隔で調查した. 相橘園の 24 樹よりあらかじめ選んだ 10 本の調査樹 (Fig. 1) から一樹当り 5 枝 10 葉（合計 50 葉）を選 びそこに寄生している雌成虫数を調查した。データは 100 葉当りの換算值で示した。

\section{結果 と考察}

1. ヘキシチアゾクス抵抗性発達の経過

ミカンハダニの個体群増加には乾燥(60 70\%R.H.)
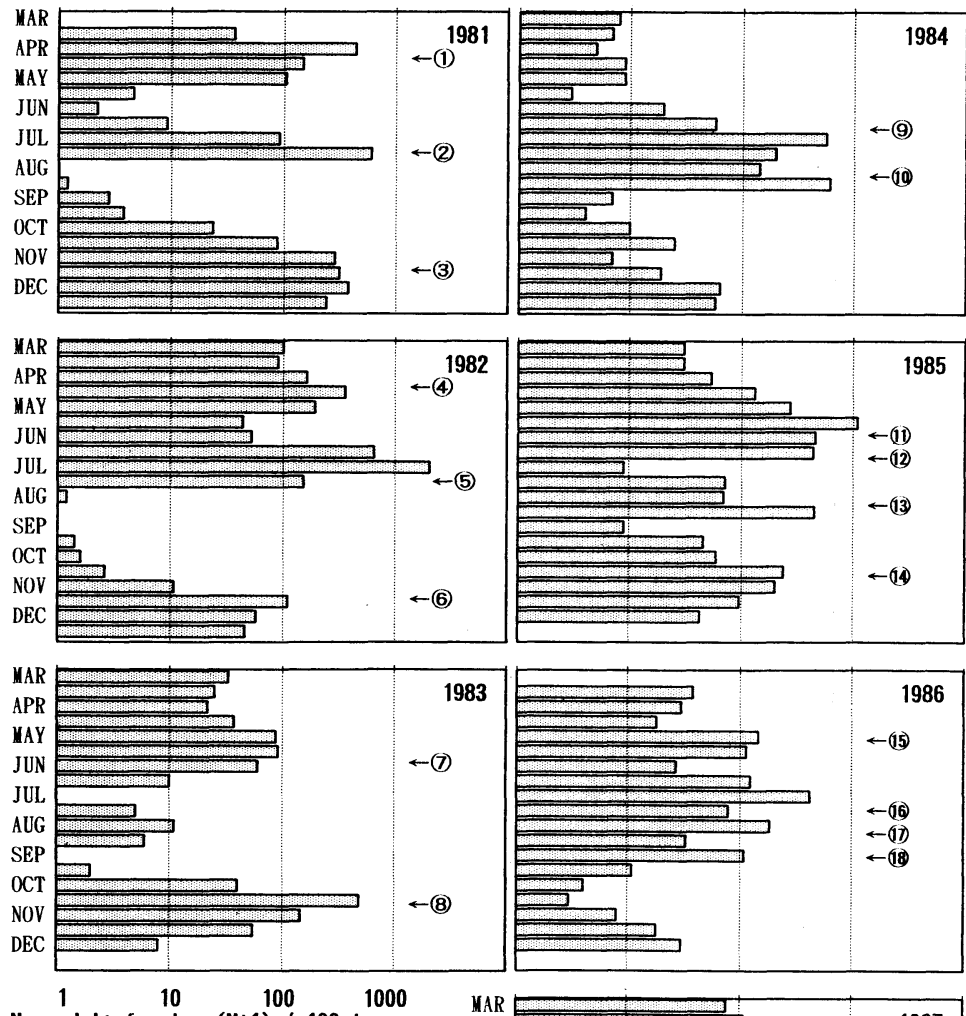

No. adult females $(N+1) / 100$ leaves

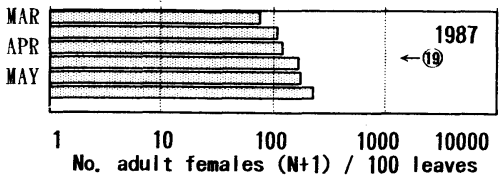

Fig. 2 Population fluctuation of citrus red mite in the citrus orchard applied with hexythiazox in 1981-1987.

The census was conducted every 15 days. Data represent average number of adult females of citrus red mite on 10 investigated trees shown in Fig. 1 (b). Arrows ( $\leftarrow)$ with numbered circle indicate selection treatments with hexythiazox. 
Table 2 Comparison of susceptibilities to hexythiazox among the citrus red mites collected from different trees in the orchard after 19th selection with hexythiazox.

\begin{tabular}{|c|c|c|c|c|c|}
\hline \multirow{2}{*}{ Strain } & \multicolumn{3}{|c|}{ Susceptibility to hexythiazox ${ }^{a}$ ) } & \multicolumn{2}{|c|}{$\begin{array}{c}\text { Resistance } \\
\text { ratio }^{c)}\end{array}$} \\
\hline & Slope $\left.^{b}\right)$ & $\begin{array}{c}\mathrm{LC}_{50}(95 \% \mathrm{CL}) \\
(\mathrm{ppm})\end{array}$ & $\begin{array}{c}\mathrm{LC}_{95}(95 \% \mathrm{CL}) \\
(\mathrm{ppm})\end{array}$ & $\mathrm{LC}_{50}$ & $\mathrm{LC}_{95}$ \\
\hline Unselected & 2.2 & $1.1(0.84-1.5)$ & $6.4(3.4-9.2)$ & 1 & 1 \\
\hline Tree No. 1 & 1.3 & $22(11-62)$ & $430(91-880)$ & 20 & 68 \\
\hline Tree No. $\left.5^{d}\right)$ & 一 & $\left.>8000(\mathrm{ND})^{\mathrm{f}}\right)$ & $>8000(\mathrm{ND})$ & $>7300$ & $>1300$ \\
\hline Tree No. 6 & 0.6 & $27(6.7-190)$ & $>8000(\mathrm{ND})$ & 25 & $>1300$ \\
\hline Tree No. 7 & 1.2 & $42(16-120)$ & $1000(72-1800)$ & 38 & 160 \\
\hline Tree No. $\left.9(\mathrm{~A})^{\text {e }}\right)$ & - & $>8000(\mathrm{ND})$ & $>8000(\mathrm{ND})$ & $>7300$ & $>1300$ \\
\hline Tree No. 9 (B) & 0.7 & $520(83-1600)$ & $>8000(\mathrm{ND})$ & 470 & $>1300$ \\
\hline
\end{tabular}

a) Control efficacy (Percent of eggs unable to develop to the adult after treatment).

b) Slope of regression equation.

c) LC value of mites from each tree/LC value of unselected mites.

d) Mortalities of mites from Tree No. 5 at 8000 and $2000 \mathrm{ppm}$ were 13 and 2\%, respectively.

e) Mortalities of mites from Tree No. 9 (A) at 8000 and $2000 \mathrm{ppm}$ were 41 and $4 \%$, respectively.

f) ND: not determined.

とある程度の高温 $\left(25 \sim 26^{\circ} \mathrm{C}\right)$ が重要で，この影響を 受けて，5 6 月頃と 10 月頃に個体数のピークをもつ 年間二山型の発生が基本となる ${ }^{15)}$ ．また，ミカン八ダニ の発育速度は高温期には速くなり, 成虫の生存期間は温 度が高くなるに従い短くなる ${ }^{2,3}$. このようなミカン八 ダニの生態およびへキシチアゾクスの殺ダニ特性をふま えると，へキシチアゾクスの防除効果は，秋期よりも 春〜夏期に優れると考兄られる. 7 月中旬の散布で, 50〜60 日間ミカン八ダニの発生を抑えた防除効果試験 も報告されている1).

Table 1 には，へキシチアゾクス淘汰相橘園における ミカン八ダニの卵のへキシチアゾクスに対する感受性の 変化を, また Fig. 2 には, ミカン八ダニの発生消長と ヘキシチアゾクスの処理時期を示した.

最初の 1 年間のへキシチアゾクスの 3 回散布により, やや感受性が低下する傾向が認められ抵抗性比が約 3 倍 になったが，散布によるミカン八ダニの密度低下は観察 された. その後 1982 年から 1984 年をで合計 10 回の 散布でも抵抗性レベルはほとんど変化せず，散布による ミカン八ダニの密度低下も観察された．この 2 3 倍の 感受性低下は, ミカン八ダニの一般的な活力の上昇, い わゆる vigor tolerance でへキシチアゾクスに強くな ったことが原因と考学られた. 9 回目の散布でやや密度 回復が速い傾向にあるが，これは散布水量が 1984 年の 基準量の半分 $(40 l)$ であったためと思われた. 1985 年の 11 回目の淘汰処理から夏期の散布でも密度抑制期 間が短くなり, 年間 4 回の散布頻度になったが, 感受性 検定の結果では, 抵抗性の発達は認められなかった。
1986 年にも年間 4 回の散布が必要となり，へキシチア ゾクスの密度抑制効果の低下が著しくなった. 16 回目 の散布後では，LC $\mathrm{LC}_{95}$ 值の抵抗性比が約 8 倍になり，こ の頃から抵抗性レベルが徐々に高まった. 18 回目の淘 汰処理では散布による密度低下は認められたものの, 後 述するように，この散布によって一部の樹に寄生するミ カン八ダニで, ヘキシチアゾクス抵抗性が発達したこと が感受性検定の結果判明した. 1987 年の 19 回目の散 布では, 散布による密度低下は認められなかった。

以上の結果から，本相檑園におけるミカン八ダニのへ キシチアゾクスに対する抵抗性発達は，連続散布という 特殊な処理方法にもかかわらず 6 年間 18 回散布後に認 められ，その速度は遅いものであった。

\section{2. 寄生樹間におけるへキシチアゾクスに対する感受 性の違い}

Table 2 には，異なる調査樹から探集したミカン八ダ ニのへキシチアゾクスに対する感受性をまとめた．採集 した時期は, ヘキシチアゾクス抵抗性発達が認められた 直後の 1987 年 5 月 22 日であった.この調査は, 18 回 目にも予兆が認められたのに加え，19 回目のへキシチ アゾクスの淘汰処理による密度抑制効果が樹ごとに異な っていたため，その原因を明らかにする目的で行なった ものである. その結果, 樹 No. 5 に寄生するミカン八 ダニの感受性がもっとも低く, $\mathrm{LC}_{50}$ 值は $8000 \mathrm{ppm}$ 以 上であった．樹 No. 5 におけるミカン八ダニの寄生密 度は, 1986 年 9 月 5 日の 18 回目淘汰処理後の 10 月 中旬から増加傾向にあり, 19 回目の淘汰処理前後でも 寄生密度がもっとも高かった(Table 3).これは, 後述 
Table 3 Differences of population fluctuation of the citrus red mite among trees in the hexythiazox selected orchard in 1981, 1986 and 1987.

\begin{tabular}{|c|c|c|c|c|c|c|c|c|c|c|c|c|}
\hline \multirow{2}{*}{$\begin{array}{c}\text { Date of } \\
\text { sampling }\end{array}$} & \multicolumn{11}{|c|}{ No. adult females/100 leaves on each tree ${ }^{a}$} & \multirow{2}{*}{$\begin{array}{l}\text { Date of } \\
\text { selection }\end{array}$} \\
\hline & (1) & (2) & (3) & (4) & (5) & (6) & (7) & (8) & (9) & $(10)$ & Ave. & \\
\hline \multicolumn{13}{|l|}{1981} \\
\hline Mar. 16 & 86 & 52 & 32 & 6 & 14 & 46 & 0 & 84 & 14 & 18 & 35 & \multirow{7}{*}{$\begin{array}{l}\text { Apr. } 21 \\
\text { (1st) }\end{array}$} \\
\hline Apr. 2 & 88 & 28 & 30 & 2 & 80 & 74 & 8 & 58 & 64 & 6 & 44 & \\
\hline 15 & 152 & 110 & 36 & 10 & 280 & 270 & 26 & 204 & 304 & 74 & 147 & \\
\hline 30 & 44 & 78 & 86 & 54 & 174 & 158 & 30 & 158 & 180 & 54 & 102 & \\
\hline May 15 & 0 & 24 & 2 & 0 & 0 & 2 & 0 & 0 & 8 & 0 & 4 & \\
\hline \multirow{2}{*}{ Jun. $\begin{array}{r}1 \\
16\end{array}$} & 0 & 10 & 0 & 0 & 0 & 0 & 2 & 0 & 0 & 0 & 1 & \\
\hline & 2 & 40 & 4 & 4 & 12 & 2 & 2 & 2 & 8 & 6 & 8 & \\
\hline \multirow{3}{*}{ Jul. } & 6 & 218 & 44 & 58 & 180 & 18 & 30 & 110 & 78 & 152 & 89 & \\
\hline & 120 & 1274 & 540 & 358 & 762 & 172 & 390 & 824 & 728 & 872 & 604 & Jul. 16 \\
\hline & 0 & 0 & 0 & 0 & 0 & 0 & 0 & 0 & 0 & 0 & 0 & (2nd) \\
\hline Aug. 14 & 2 & 0 & 0 & 0 & 0 & 0 & 0 & 0 & 0 & 0 & 0.2 & \\
\hline 31 & 6 & 0 & 0 & 0 & 0 & 4 & 2 & 0 & 0 & 6 & 2 & \\
\hline \multirow{2}{*}{ Sep. 1} & 4 & 0 & 0 & 0 & 0 & 12 & 4 & 8 & 0 & 0 & 3 & \\
\hline & 44 & 0 & 2 & 0 & 8 & 28 & 52 & 80 & 12 & 0 & 23 & \\
\hline Oct. 16 & 190 & 2 & 0 & 10 & 98 & 152 & 176 & 184 & 24 & 20 & 86 & \\
\hline \multirow{2}{*}{$\begin{array}{r}\text { Nov. } 9 \\
16\end{array}$} & 398 & 14 & 106 & 12 & 314 & 574 & 388 & 680 & 238 & 64 & 279 & Nov. 10 \\
\hline & 398 & 38 & 112 & 14 & 396 & 568 & 386 & 838 & 298 & 64 & 311 & (3rd) \\
\hline \multirow{2}{*}{$\begin{array}{r}1 \\
15\end{array}$} & 200 & 18 & 138 & 22 & 402 & 688 & 520 & 1104 & 442 & 160 & 369 & \\
\hline & 144 & 4 & 44 & 10 & 196 & 326 & 452 & 776 & 298 & 114 & 236 & \\
\hline \multicolumn{13}{|l|}{1986} \\
\hline \multirow{2}{*}{$\begin{array}{lr}\text { Mar. } & 15 \\
\text { Apr. } & 1\end{array}$} & 6 & 8 & 68 & 12 & 26 & 34 & 16 & 26 & 124 & 52 & 37 & \\
\hline & 10 & 22 & 14 & 6 & 10 & 10 & 8 & 26 & 110 & 76 & 29 & \\
\hline 15 & 6 & 10 & 32 & 16 & 4 & 8 & 20 & 30 & 22 & 24 & 17 & \\
\hline \multirow{2}{*}{$\begin{array}{r}30 \\
\text { May } 14\end{array}$} & 86 & 52 & 138 & 28 & 44 & 130 & 90 & 122 & 534 & 196 & 142 & May 1 \\
\hline & 46 & 26 & 106 & 30 & 46 & 170 & 124 & 102 & 266 & 180 & 110 & (15th) \\
\hline \multirow{2}{*}{$\begin{array}{r}\text { Jun. } 2 \\
16\end{array}$} & 14 & 12 & 28 & 2 & 34 & 72 & 4 & 50 & 20 & 26 & 26 & \\
\hline & 86 & 34 & 120 & 32 & 114 & 210 & 132 & 162 & 202 & 128 & 122 & \\
\hline \multirow{2}{*}{ Jul. } & 354 & 224 & 700 & 212 & 196 & 836 & 380 & 300 & 512 & 474 & 419 & Jun. 26 \\
\hline & 82 & 62 & 136 & 36 & 16 & 132 & 100 & 72 & 78 & 44 & 76 & (16th) \\
\hline Aug. 1 & 44 & 218 & 206 & 102 & 40 & 424 & 260 & 130 & 198 & 170 & 179 & Aug. 1 \\
\hline 15 & 10 & 26 & 44 & 16 & 8 & 62 & 48 & 34 & 50 & 20 & 32 & (17th) \\
\hline Sep. 2 & 50 & 98 & 324 & 102 & 68 & 174 & 102 & 72 & 32 & 36 & 106 & Sep. 5 \\
\hline 18 & 6 & 8 & 50 & 2 & 6 & 10 & 0 & 2 & 8 & 6 & 10 & (18th) \\
\hline Oct. 2 & 2 & 6 & 6 & 2 & 8 & 0 & 0 & 2 & 4 & 2 & 3 & \\
\hline 15 & 4 & 0 & 14 & 0 & 2 & 2 & 0 & 2 & 0 & 0 & 2 & \\
\hline 31 & 0 & 2 & 4 & 2 & 54 & 2 & 0 & 0 & 6 & 4 & 7 & \\
\hline Nov. 14 & 0 & 2 & 64 & 2 & 86 & 6 & 0 & 0 & 10 & 0 & 17 & \\
\hline Dec. 3 & 0 & 0 & 46 & 0 & 120 & 32 & 0 & 20 & 68 & 0 & 29 & \\
\hline 1987 & & & & & & & & & & & & \\
\hline Mar. 2 & 34 & 4 & 188 & 4 & 296 & 90 & 48 & 32 & 44 & 6 & 75 & \\
\hline 16 & 16 & 14 & 302 & 14 & 434 & 96 & 124 & 8 & 134 & 26 & 107 & \\
\hline Apr. 1 & 26 & 2 & 326 & 8 & 536 & 48 & 16 & 44 & 100 & 82 & 119 & \\
\hline 15 & 46 & 56 & 170 & 26 & 844 & 134 & 120 & 34 & 124 & 94 & 165 & Apr. 17 \\
\hline 30 & 8 & 38 & 54 & 14 & 1132 & 74 & 48 & 44 & 206 & 114 & 173 & (19th) \\
\hline May 15 & 38 & 64 & 48 & 28 & 1316 & 30 & 62 & 254 & 330 & 40 & 221 & \\
\hline
\end{tabular}

a) Location of numbered trees are shown in Fig. 1 (b). 
するような環境的な要因よりも，ヘキシチアゾクスに抵 抗性を発現したミカンハダ二の増殖によって，淘汰処理 後に密度が増加したものと考えられた。

興味深いことに，樹 No. 9 の樹 No. 5 に隣接する枝 から採集したミカンハダニ（樹 No. 9-A）の感受性も きわめて低く（LC50 值は $8000 \mathrm{ppm}$ 以上），樹 No. 5 と同程度であった）それに比べ，同じ樹 No. 9 でも樹 No. 5 と反対側の枝から採集したハダニ（樹 No. 9-B） の感受性は, 樹 No. 9-A のミカンハダニよりも高かっ た（LC50 值は $8000 \mathrm{ppm}$ 以上，Table 2). 樹 No. 9 での寄生部位による感受性の差異は, 樹 No. 5 からの

ミカンハダニの移動分散の影響によるものと考えられ た.ミカンハダ二の個体群密度が低かった樹 No. 1，樹 No. 6 および樹 No. 7 から採集したミカン八ダニでは, ヘキシチアゾクス抵抗性レベルは高いものではなかった ものの，抵抗性に関して不均質な状態であることが窥わ れた。それは，これらの調査樹のミカンハダニの抵抗性 比が， LC50 值では 20 40 であるものの LC 95 值では 68～1300 以上と大きく, しかも回帰直線の傾き (slope) も小さい傾向にあるからである.

以上の結果から，同一の柑橋園内でも寄生樹ごとにミ カン八ダニのへキシチアゾクスに対する感受性が異なっ ていることが明らかとなった。

\section{3. 寄生樹によるミカンハダニの発生消長の違い}

一般にハダ二類の生息場所内での空間分布は一様では なく ${ }^{15,16)}$ ，寄生植物間でも寄生植物内でも分布が異なる 場合が多い，ミカン八ダニでは3)，園内における樹間分 布は集中分布であり，分布集中度は発生初期に高く，密 度が高くなると集中度が低下すること，また薬剤散布後 も集中度が高くなることが報告されている．さらに，樹 間分布の集中度が，樹内分布に比較して著しく高い傾向 にあるが，これは殺ダニ剤を用いた防除における局所的 な生き残りに起因するとされている。

本研究では，へキシチアゾクスによる淘汰試験を行な った柑䄦園において 10 本の調查樹を抽出し，樹ごとの ミカンハダ二の個体群密度を実験当初の 1981 年 3 月 から調査した。ここでは，淘汰試験を開始した当初であ りヘキシチアゾクスの感受性低下が認められていない 1981 年と, ヘキシチアゾクスの散布頻度が高くなった 1986 年からへキシチアゾクス感受性低下が認められた 1987 年までを例として, 寄生樹ごとのミカンハダニ雌 成虫の個体群密度の変化を Table 3 にまとめた，その 結果, 柑橘園内の寸べての調查樹に対して, 一般防除も 含め薬剤処理と同じ栽培管理がされているにもかかわら ず，どの調査時でも樹ごとにミカンハダニの個体群密度
の差が観察された。また，ミカンハダ二の寄生密度の高 い樹が特定されることもなかった.

このようにミカン八ダニの発生消長が同一園内でも寄 生樹によって異なる理由は, 淘汰薬剂に対する感受性差 や散布むらによる生き残り個体数の差に加え, 移動・分 散を引き起こす要因が，寄生樹ごとに空間的にも時間的 にも異なっているためと思われる. 一般的にいわれるよ うに, 樹を取り巻く微気象等の環境条件, 季節やハダニ の加害状態によって左右される食物としての樹の栄養生 理状態 ${ }^{17,18)}$ や樹勢などは，同一園内でも樹ごとに異なっ

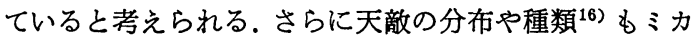
ンハダニの園内分布に影響すると思われる. 本淘汰圊場 ではミカンハダニの天敵として少なくとも，ハダニアザ ミウマ (Scolothrips takahashii PRIESNER), ヒメ八 ダニカブリケシハネカクシ (Oligota kashmirica benefica NAOMI), ハダニカブリケシハネカクシ (Oligota yasumatsui KISTNER), およびハモリダニ (Anystis baccarum LINNAEU) が確認された.

ハダ二類の個体群密度の変異が樹（植物）内よりも樹 (植物）間で大きいことはこれまでにも報告されてお $\eta^{16,19)}$ ，野外の柑㰌園ではミカン八ダニにとっての生息 場所の環境の異質性が常に存在することが示唆された. これは,ミカンハダニのへキシチアゾクス抵抗性発達に も影響する生物的/生態的要因の一つとも考えられる. したがって，同一柑橘園内でもミカンハダ二の発育にと って好適な樹や個体群密度の高い樹から，最初に抵抗性 が発達してくる可能性も否定できない. よって，ミカン ハダニのへキシチアゾクス抵抗性対策の一環として感受 性をモニタリングする際には，ミカン八ダニの樹ごとの 個体群密度と感受性との関係にも留意する必要があると 思われた。

\section{4. 淘汰相榣園におけるへキシチアゾクス抵抗性発達 の特徽}

淘汰試験を行なった柑㰌園でのへキシチアゾクス抵抗 性発達の様相の特徴として，次の 2 点が挙げられる.第 1 点は，抵抗性発達速度が遅かったことである．第 2 点 は，抵抗性集団が相䨩内で一斉に出現したのではな く，局所的に一部の集団で高い抵抗性が発達したことで ある・

殺虫剂殺ダ二剂抵抗性発達は，薬剤に対する適応現象 であり避けられないものと考えられている．そしてそれ は，遺伝的，生物的および防除的要因の影響を受け $3^{20,21)}$. 八ダ二類はとくに，他の生物に比べ抵抗性発達 に関与する生物的および生態的要因を多くもっていると 考えられる4,5). たとえば，産雄単為生殖を行なうこと， 
移動性が低く殺ダニ剂を処理した生息場所に留まりやす いこと，および繁殖速度が速いことなどである。

しかし，淘汰試験を行なった柑绣園のミカン八ダニで はへキシチアゾクス抵抗性発達速度が遅かった. その原 因として次のことが考えられる. まず第一に, 淘汰試験 を開始した 1981 年当時では，それまでにへキシチアゾ クスのような新規な脱皮阻害剂が用いられたことがな かったため, ヘキシチアゾクス抵抗性遺伝子の初期頻度 がおそらく非常に低かったのであろう．第 2 に， 一キ シチアゾクスのみの連続散布を基本として他の殺ダニ剤 は使用せず，病害虫防除を極力減らした淘汰方法にも原 田あるのかもしれない. 第 3 に，遺伝的な側面からも 次のように考えられる. ミカン八ダニのへキシチアゾク ス抵抗性は，不完全劣性の遺层をする ${ }^{6)}$ ため，抵抗性の ヘテロ接合体をもつ個体（以下，へテロ個体）のへキシ チアゾクスに対する感受性は，感受性系統に近い。た とえば，卵から成虫に至るまでの発育阻害力の $\mathrm{LC}_{95}$ 值 は，感受性系統と抵抗性系統でそれぞれ $0.4 \mathrm{ppm}$ と $8000 \mathrm{ppm}$ 以上であり，一方，一テロ個体では 4 16 $\mathrm{ppm}$ であった。淘汰試験を行なった相㰌園のミカンハ ダニの集団にとって，25 ppm のへキシチアゾクスの散 布は高い淘汰圧であり，感受性個体とともに淘汰過程で 生じるへテロ個体をかなり殺すことができたとも考えら れる、第4 に，淘汰実験を行なった柑橋園は野外にある ため, へキシチアゾクスを散布していない隣接した柑檑 園から，へキシチアゾクス感受性ミカンハダニが淘汰試 験を行なった柑橋園へ飛び込むことも可能であった。し たがって，感受性個体がへテロ個体や抵抗性個体と自由 に交配したため，抵抗性のホモ個体がなかなか出現でき なかった可能性もある. 少なくとも以上の原因から， カン八ダニの集団中に抵抗性遺层子がなかなか蓄積され ず，結果として抵抗性発達が遅かったと推察された．理 論的にも，Tabashnik \& $\mathrm{Croft}^{22)}$ が，コンピューター シミュレーションによって，抵抗性遗后子の初期頻度が 低い場合や，感受性個体群の移入がある場合，さらに散 布濃度が高くへテロ個体群も感受性個体群も殺してしま うような場合には，抵抗性発達が遅いと予測している。

淘汰試験を行なった柑绣園において，人キシチアゾク ス抵抗性集団が柑橘園内で一斉に出現したのではなく， 局所的に一部の集団で高い抵抗性が発達したが，この原 因は次のように推察される。一般に，八ダニ類は，世代 の分離が明瞭でなく，移動性も小さく，近親交配も比較 的自由に行なわれるため ${ }^{4,5)}$ ，狭い生息場所で血縁度の 高い集団を形成しやすい，さらに，八ダ二類は産雄単為 生殖で繁殖し，この繁殖システムは両性生殖と比べ，薬
剤抵抗性をより速く発達させると予測されている ${ }^{23)}$. ま た, 産雄単為生殖を行なう八ダ二類では, 遺伝的変異が 集団間では大さく集団内では小さいと考えられてい $ろ^{4,23)}$. したがって， 一キシチアゾクスの淘汰処理に伴 い，いったん血縁度の高いごく小さな集団でへキシチア ゾクスに対する抵抗性遺伝子が蓄積され始めると, 産雄 単為生殖によってその頻度が急速に高まり, 抵抗性個体 が出現したのであろう.その結果, 局所的な抵抗性発達が 観察されたものと推察された. 他の殺ダ二剂抵抗性発達 においても同様の現象が生じているものと思われるが, これまでに本報告のような調査例は報告されていない。

\section{5. 抵抗性対策}

ミカンハダニの殺ダ二抵抗性発達速度には，さまざま な要因 ${ }^{20,21)}$ が関与しているため，一概に予測するのは 困難であり地域差や柑橋園による差があるのが普通であ る ${ }^{10)}$. たとえば，露地の柑橋園 と八ウスの柑㰌園とで は, ミカンハダニの発生消長が大きく異なるし, へキシ チアゾクスの残効力も異なるであろう. また，柑檑の栽 培地域ごとに薬剤の散布歴が異なっているため, ミカン ハダ二の殺ダ二剤に対する抵抗性スペクトラムや代謝能 力も異なるものと考号らる.さらに，人キシチアゾク ス抵抗性遺伝子の初期頻度にも地域差があるとも思われ る.このように，抵抗性発達に関与する生物的，遺伝的 要因および防除的要因の一部は，使用者による制御が不 可能である. 本淘汰試験でも明らかになったように，抵 抗性の発達は同一園内でも局所的に発現することが予想 されるため，ミカンハダ二の寄生密度が高い樹をあらか じめ知り対処しておくことは，抵抗性対策の一助になる であろう. また, 本研究ではへキシチアゾクスの連用散 布という特殊な条件下でありながら抵抗性発達は遅かっ た.しかし一般的に抵抗性発達を回避および遅延させる ためには，へキシチアゾクスの連続散布は極力避け， 、 キシチアゾクスの防除効果がもっとも期待される初夏か ら夏期の年 1 回使用を行なうことが基本的に薦められ る.そのためには，それぞれの栽培地での有効薬剤をあ らかじめ知り，へキシチアゾクスと作用機構の異なる薬 剂とのローテーション散布や混合による散布を行なうこ とが，現実的で有効な抵抗性対策であると思われる。ま た，柑檑園の各種病害虫防除には，天敵類に影響の少な い薬剤を使用することも重要であると考えられる。

\section{要 約}

柑㰌園におけるミカン八ダニのへキシチアゾクス抵抗 性発達の樣相を把握し，抵抗性対策を考えるため，静岡 県榛原郡の日本曹達株式会社榛原農業研究所内の 24 樹 
からなる柑橘園において淘汰試験を行なった。 6 年間で 18 回のへキシチアゾクス連用散布 $(25 \mathrm{ppm})$ で, $\mathrm{LC}_{50}$ 值が 8000 ppm 以上の高いレベルに抵抗性が発達した。 連続散布という特殊な処理体系でありながら抵抗性発達 速度は遅かった. 最初の 4 年間は年 $2 \sim 3$ 回の散布でミ カンハダニの密度抑制が可能であったが，次の 2 年間で は効果が低下し年 4 回もの散布を必要とした。また，同 一園内でも樹ごとにミカン八ダニの発生密度が異なるだ けでなく，へキシチアゾクスに対する感受性も異なり， ヘキシチアゾクス抵抗性は, 特定の樹に奇生するミカン ハダニの集団で局所的に発達したと考えられた。

本研究の実施にあたり，ミカンハダニを分譲していた だいた農林水産省果樹試験場の是永龍二博士および静岡 県柑欈試験場の古橋嘉一博士に厚くお礼申し上げる. ま た有益な助言，ご教示ならびに本稿の校閲をいただいた 名古屋大学農学部教授 宮田 正博士, 日本曹達株式会 社小田原研究所生物研究所および榛原農業研究所の所員 一同に感謝の意を表する.

\section{引用 文 献}

1) 山田富夫 ·帰山 稔 - 松井宣夫 - 米田 渥：農薬 誌 12, 327 (1987)

2) 安田 誠: 応動昆 26, 52 (1982)

3) 古橋嘉一: 静岡県柑橋試験場特別報告第 4 号 56 pp., 1980

4) 浅田三津男：農薬誌 3, 61 (1978)

5) B. A. Croft \& H. E. Van De Baan: Exp. Appl. Acarol. 4, 277 (1988)

6) 山本敦司 - 米田 渥 - 芳村綾子：日本農薬学会第 13 回大会講演要旨集, p. 73, 1988

7) W. H. Reissig \& L. A. Hull: J. Econ. Entomol. 84, 727 (1991)

8) W. G. Thwaite: Exp. Appl. Acarol. 11, 73 (1991)

9) G. A. Herron, V. Edge \& J. Rophail: Exp. Appl. Acarol. 17, 433 (1993)

10) J. Keiding: "Pesticide Resistance: Strategies and Tactics for Management," ed. by Committee on Strategies for the Management of Pesticide Resistant Pest Population, Nat. Acad. Press, Washington, D.C., pp. 279-297, 1986.

11) 真梶徳純：植物防疫 20,57 (1966)

12）菅原寛夫 ·真梶德純 - 斎藤哲夫 - 田中 学：果樹 ハダ二類の薬昘抵抗性に関する研究，日本植物防 疫協会, pp. 11-24, 1973

13) W. S. Abott: J. Econ. Entomol. 18, 265 (1925)

14) D. J. Finney: "Probit Analysis," Cambridge Univ. Press, London, 383 pp., 1971

15) 中尾舜一： ダ二学の進歩 その医学・農学・獣医 学・生物学にわたる展望, 佐々 学・青木淳一 編, 北隆館, pp. 251-278, 1977

16) M. W. Sabelis: "Spider Mites. Their Biology, Natural Enemies and Control. Volume 1A," ed. by W. Helle \& M. W. Sabelis, Elsevier Science Publishers, Amsterdam, pp. 337-350, 1985

17) A. Crooker: "Spider Mites. Their Biology, Natural Enemies and Control. Volume 1A," ed. by W. Helle \& M. W. Sabelis, Elsevier Science Publishers, Amsterdam, pp. 149-163, 1985

18) A. Tomczyk \& D. Kropczynska: "Spider Mites. Their Biology, Natural Enemies and Control. Volume 1A," ed. by W. Helle \& M. W. Sabelis, Elsevier Science Publishers, Amsterdam, pp. 317-329, 1985

19) V. P. Jones \& M. P. Parrella: J. Econ. Entomol. 77, 75 (1984)

20) G. P. Georghiou \& C. E. Taylor: J. Econ. Entomol. 70, 319 (1977)

21) G. P. Georghiou \& C. E. Taylor: J. Econ. Entomol. 70, 653 (1977)

22) B. E. Tabashnik \& B. A. Croft: Environ. Entomol. 11, 1137 (1982)

23) R. H. Crozier: "Spider Mites. Their Biology, Natural Enemies and Control. Volume 1A," ed. by W. Helle \& M. W. Sabelis, Elsevier Science Publishers, Amsterdam, pp. 201-222, 1985 